\title{
Recent Archeological Work in Kachemak Bay, Gulf of Alaska
}

\author{
WILLIAM B. WORKMAN', JOHN E. LOBDELL ${ }^{2}$, and KAREN WOOD \\ WORKMAN $^{3}$
}

\begin{abstract}
Excavations since 1974 have built upon de Laguna's pioneering classification of Pacific Eskimo prehistory. The Chugachik site (SEL 033) yielded abundant artifactual and paleoenvironmental information dated mainly between c. 350 B.C. and 250 A.D. While artifacts were scarce at Cottonwood Creek (SEL 030), dated at about 200 A.D., data on human biology, paleopathology, social stratification and mortuary ceremonialism were recovered. The Yukon Island Fox Farm Bluff site (SEL 041) dates to $c$. 500-900 A.D. and yielded a new culture showing connections with the Alaska Peninsula. Future research should focus on the earlier prehistory of the bay, the classic problem of the Pacific Eskimo-Tanaina Athapaskan transition, and the paleoenvironmental record.
\end{abstract}

\begin{abstract}
RÉSUMÉ. Les fouilles réalisées depuis 1974 ont accèléré le défrichage de la connaissance de la préhistoire des Esquimaux du Pacifique. Le site de CHUGACHIK produisait des artefacts abondants et une information d'environnement fossile, datée principalement de 350 ans avant J.C. et 250 ans après J.C. A Cottonwood Creek, les artefacts étaient dispersés, datés de 200 ans après J.C. environ, mais on recuellait des renseignements sur la biologie humaine. la paléopathologie. l'échelle sociale et le cérémonial mortuaire. Au site de l'ile Yukon. "Fox Farm Bluff'. daté de 500 à 900 ans après J.C., on y recontrait une nouvelle civilisation ayant des rapports avec celle de la Péninsule d'Alaska. Dans l'avenir, la recherche devrait se concentrer sur la préhistoire plus ancienne de la baie, le probleme classique de la transition Esquimaux du Pacifique - Tanaina Athapascien et sur le paléoenvironnement.
\end{abstract}

Traduit par Alain de Vendegies, Aquitaine Company of Canada Ltd.

\section{INTRODUCTION}

In 1883 the professional collector of ethnographic specimens Johan Jacobsen tested a village site in Kachemak Bay, describing a clear separation between a pottery-using and an historic component (Jacobsen, 1977; Dumond and Mace, 1968). After this auspicious beginning no further progress was made for almost 50 years. In 1930 Frederica de Laguna began a three-season program of archeological research in Kachemak Bay which culminated with the publication of The Archaeology of Cook Inlet, Alaska in 1934. This was the first essentially modern monograph on Alaskan prehistory based on extensive excavation in a limited area. In thoroughly modern fashion, de Laguna's choice of the Cook Inlet area as a research target was made with a problem in mind: the relationships over time between the Pacific Eskimo and Tanaina Athapaskan cultures (1934). Although her investigations did not solve this problem, she established a durable and useful cultural sequence for some 1500 years of Pacific Eskimo prehistory in an hitherto unknown area, working under extreme logistic and scientific difficul-

\footnotetext{
'Department of Anthropology, University of Alaska, Anchorage, Alaska 99504 ${ }^{2}$ Department of Anthropology, Anchorage Community College, Anchorage, Alaska 99504 33310 East 41st Avenue, Anchorage, Alaska 99504
} 


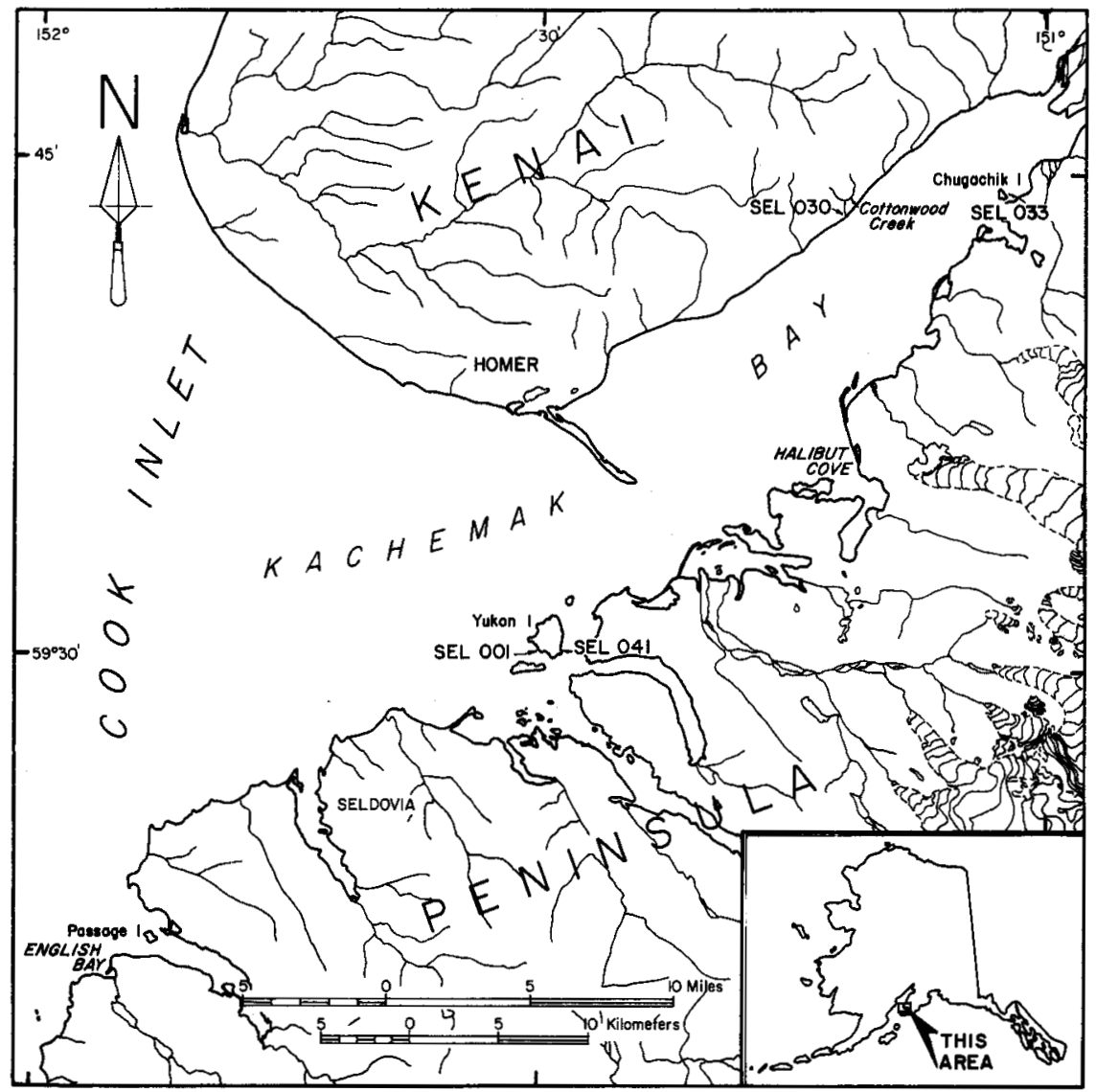

FIG. 1. Map of Kachemak Bay showing principal sites and geographic features.

ties. The results of her investigations have played a central role in the development of Gulf of Alaska archeology (Workman and Workman, 1975).

Despite this good start and the proximity of Kachemak Bay to the most populated part of the state, little further work was done until 1974. In that year we began a long-term project in Kachemak Bay, which has resulted in major excavations at Cottonwood Creek and on Chugachik and Yukon Islands (Fig. 1). Our selection of this area for a long-term project was motivated by logistic and aesthetic considerations as well as scientific ones. Kachemak Bay is easily accessible by road from Anchorage and it provides a beautiful and relatively dry window into the rich prehistoric past of the Gulf of Alaska. In this paper we briefly summarize the results of our work, specify some of the major problems confronted, and suggest topics and approaches that deserve future consideration.

Kachemak Bay is a deep embayment of the western end of the Kenai Peninsula (Fig. 1). The north and south shores present very different aspects with 
significant impact upon their desirability as habitats for North Pacific maritime hunters. The north shore is straight and rimmed with spectacularly bedded sediments of Tertiary age which give way inland to rolling hills (Karlstrom, 1964). The Homer spit projects four miles into the bay and extensive mud flats have built up along the north shore. Apparently this coast had little to offer aboriginal man since there is only one substantial archeological site along it, Cottonwood Creek (SEL 033).

The south shore in contrast is convoluted, dotted with islands and backed by high mountains which shelter several active glaciers (Fig. 1). Offshore waters are deep. This complex coast was the focus of aboriginal occupation. Kachemak Bay thus illustrates in microcosm a topographic distinction between complex mountain-backed coasts and low simple shores that we believe has been ecologically and culturally significant throughout the span of northern North Pacific prehistory (W. Workman, 1980). Clearly Pacific Eskimos and their ancestors have long preferred the complex to the simple.

Although surprisingly poorly known from a biological point of view, Kachemak Bay is an extremely productive body of water (U.S. Department of Commerce, 1977). Harbor seals and porpoises are abundant and the lesser whales visit the area. Sea otter and sea lion are available locally. Sea birds and water fowl teem in season and halibut and other economically significant marine fish thrive. Salmon are also available, although the area lacks salmon streams comparable in stature and diversity of yield to those further north along the Kenai Peninsula (State of Alaska Department of Fish and Game, 1978). Inter-tidal invertebrates were widely available and caribou herds formerly ranged the adjacent uplands (Lutz, 1974). Marmots were popular in aboriginal menus. Black and brown bear, moose, beaver, and other game appear more rarely in archeological sites.

\section{THE CULTURAL SEQUENCE}

De Laguna's basic accomplishment was the definition of a long-lived Pacific Eskimo cultural tradition. Although she did not use the term, we incline towards designating this the Kachemak tradition, following the the usage of Donald Clark $(1970 ; 1975)$ for Kodiak Island where similar materials are found. De Laguna (1934) defined four periods within this tradition: Kachemak I, Kachemak II, Kachemak Sub-III, and Kachemak III. The Kachemak tradition ended long before the coming of Europeans to the area. De Laguna's Kachemak IV period lies outside the Kachemak tradition and will be discussed later. The great majority of de Laguna's material was derived from excavations at Cottonwood Creek on the north shore of the bay and two sites (SEL 001, SEL 041) on Yukon Island, and is attributable to Kachemak III.

The criteria on which this sequence is based are subject to additional refinement as the data base expands. In general, these periods follow a fairly smooth developmental continuum characterized by the gradual replacement of implements of flaked stone by ground slate counterparts; innovation of large notched pebble net weights and their reduction in size over time; possible changes in 
domestic architecture; the development starting in Kachemak Sub-III of obsessively high levels of craftsmanship applied even to simple everyday tools, jewelry, and bizarre burial ceremonialism featuring dismembered and otherwise mutilated corpses, and refinements such as placing artificial eyes in the orbits prior to burial. Other traits distinctive of the tradition, but not the periods within it, include boulder spall scrapers, ulus, ground adzes, compound fishhook barbs, labrets and representational art. The culmination of the Kachemak tradition in Kachemak III times was followed somewhat abruptly by its withdrawal from Kachemak Bay by about 500 A.D.

\section{The Origins of the Kachemak Tradition and the Early History of the Bay}

Kachemak I is known only from a small assemblage from the bottom of the Great Midden site (SEL 001) on Yukon Island (de Laguna, 1934) and from the oldest deposits in a test trench recently dug in the Yukon Island Fox Farm site (de Laguna and K. Workman, 1979; unpublished field work, 1979). Some key artifacts are illustrated as an assemblage by Bandi (1969). Kachemak I is a basic nondescript inventory featuring flaked stone tools and a primitive-looking open socket self-armed toggle harpoon similar to some from the Norton culture on Nunivak Island (Nowak, 1974) and Cape Denbigh (Giddings, 1964) to the north. Kachemak I is not satisfactorily dated, but it probably belongs in the latter half of the Second Millennium B.C. (W. Workman, 1977a).

Maritime cultures 6000 years old and related in part to the later cultures of the area, probably including the Kachemak tradition, are now known on Kodiak Island (D. Clark, 1979) and on the Pacific shores of the Alaska Peninsula (G. Clark, 1977). The first 2000-3000 years of known North Pacific prehistory have not been defined in Kachemak Bay although there are tantalizing indications of the presence of early maritime hunters in random finds (de Laguna, 1934; 1975). If it develops that maritime settlers were slow to appreciate the richness of Kachemak Bay, the local sequence may have to be rooted in something like the Old Kiavak phase on Kodiak Island (D. Clark, 1966) or the Takli Birch phase on the Alaska Peninsula (G. Clark, 1977), both dating to the Second Millennium B.C. A notched projectile point from Halibut Cove (de Laguna, 1934) suggests the possible presence of Indian hunters of moderate antiquity in the area as well.

\section{Chugachik Island and the Middle Range of Kachemak Tradition Prehistory}

In 1974 and 1977 we excavated at the rich Chugachik Island site (SEL 033) located far upbay (Fig. 1; K. Workman, 1977; 1978). Organic preservation is excellent. The deep layers of one portion of the site are saturated, preserving wooden labrets, knives, stakes, and a birchbark carrying cradle. Spruce boughs, leaves and grass are also preserved. The prevalent matrix is a dark, soily, fairly undifferentiated midden. Human remains and defined features were extremely rare. No house pits were encountered, although an irregular series of large post molds was located at one end of the site.

Flaked stone artifacts are abundant throughout the deposit (Fig. 2). Most noteworthy are a series of small stemmed projectile points; bifaces and unifacially retouched pieces also occur. Ground slate artifacts are less frequent, with 


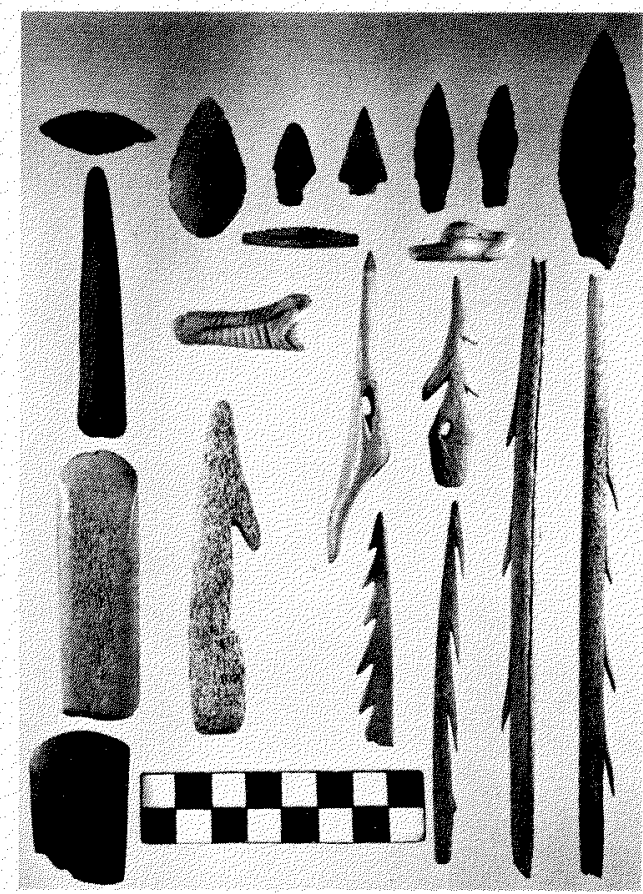

FIG. 2. Artifacts from the Chugachik Island Site (SEL 033).

Top Row: Six flaked stone bifaces and points, sideblade

Row Two: Ivory seal (?) head, incised bone piece

Row Three: Barbed dart, toggle harpoon head, bone seal (?) image, ground slate rod Row Four: Broken bone point, barbed dart, antler wedge

Bottom Row: Two bone arrowheads with blade slits, barbed bone point, greenstone adze blade

ground slate projectile or spear points appearing only in the upper levels. Land hunting activities appear to be under-represented in the faunal assemblage since we recovered 36 organic arrowheads and few land mammal bones. Labrets occur throughout the sequence, but other jewelry is concentrated in the upper levels. Over 60 awls were found, suggesting considerable attention to leather work. Three representational art objects were found (Fig. 2). A crudely carved human face was attached to a substantial piece of walrus ivory, probably an expensive trade piece from the Alaska Peninsula.

More than 1000 small notched stones were found. Several occurred in large clusters suggestive of nets and one retained between the notches traces of the fiber which had bound it. The abundance of scoter ducks in the faunal sample and area (Yesner, 1977) and the absence of any but bottom fish raise the possibility that the nets were used in fowling. The weights are small, most being under $5 \mathrm{~cm}(\mathrm{~K}$. Workman, 1977) and they do not appear to vary significantly in length over the span of the occupation.

Typologically, the material represents late Kachemak II, Kachemak Sub-III and possibly a veneer of Kachemak III. Certain artifacts show clear cross ties 
TABLE 1: Radiocarbon dates from archeological sites in Kachemak Bay

Samples with University of Georgia numbers (UGa-) are published here for the first time. For further discussion of the others see W. Workman, 1977a.

Great Midden (SEL 001), Yukon Island (de Laguna, 1975; Workman, 1977a)

$1369 \pm 102$ radiocarbon years: 581 A.D. (P-138). Run on five pieces of caribou antler from unspecified location in Kachemak III deposits.

$2706 \pm 118$ radiocarbon years: 756 B.C. (P-139). Run on eight pieces of caribou antler from Kachemak I period.

Chugachik Island Site (SEL 033) (W. Workman, 1977a)

$1475 \pm 70$ radiocarbon years: 475 A.D. (UGa-2344). Near top of midden deposit 40 $\mathrm{cm}$ below ground surface.

$1705 \pm 65$ radiocarbon years: 245 A.D. (S-1063). Eighty $\mathrm{cm}$ beneath reconstructed ground surface in section truncated by erosion.

$1940 \pm 90$ radiocarbon years: 10 A.D. (UGa-2342). Well within midden $85 \mathrm{~cm}$ beneath ground surface.

$2310 \pm 65$ radiocarbon years: 360 B.C. (S-1062). Fragments of sewn birchbark from shell layer directly above sterile subsite peat.

$2740 \pm 75$ radiocarbon years: 790 B.C. (UGa-2343). Botton of midden $218 \mathrm{~cm}$ below datum.

Cottonwood Creek (SEL 030) (W. Workman, 1977a)

$1555 \pm 75$ radiocarbon years: 395 A.D. (S-1054). Small sample found $10 \mathrm{~cm}$ beneath surface of main component midden.

$1745 \pm 65$ radiocarbon years: 205 A.D. (S-1042). Plank from a structure at the bottom of the midden $315-325 \mathrm{~cm}$ below ground surface.

$1750 \pm 125$ radiocarbon years: 200 A.D. (S-1043). Compressed plank from another structure directly atop sterile subsite soil 170 to $180 \mathrm{~cm}$ below ground surface.

Yukon Island Fox Farm Bluff Site (Workman and Lobdell, 1979)

$1130 \pm 120$ radiocarbon years: 820 A.D. (UGa-2340). Charcoal from top of the dark soil which contains the cultural material just beneath a sealing volcanic ash.

$1315 \pm 205$ radiocarbon years: 625 A.D. (UGa-2341). Upper midden lens, midpoint is out of stratigraphic order but sample is statistically indistinguishable from other two.

$1090 \pm 195$ radiocarbon years: 860 A.D. (UGa-2339). Charcoal from the lower of two midden lenses.

with the Norton culture of the Bering Sea (K. Workman, 1977) and occur early in the occupation. These artifacts include some of the small stemmed projectile points (one of which was facially ground), bifacially flaked endscapers, a notched bone adze haft and a wide, very thin medial labret. Evidence from Chugachik Island and Yukon Island II at the Great Midden site (SEL 001) on Yukon Island suggest that the most profound Norton influences occurred in Kachemak II times, shortly before the beginning of the Christian era.

Five radiocarbon dates from Chugachik Island (Table 1) are in stratigraphic order, but neither the 790 B.C. date nor the 475 A.D. date are strongly supported by the typology. The $360 \mathrm{~B}$.C. date on birchbark from saturated basal deposits is perhaps the most reasonable date for the onset of the main occupation. 
Harbour seal and porpoise were the principal game animals although marmot are also abundant. There is some beluga, and, interestingly, dungeness crab parts were encountered in the midden deposits. Large land animals are represented mostly by artifactually modified elements. Only bottom-dwelling halibut, cod, sculpin, and starry flounder, presumably taken with hook and line, represent the fishes. A variety of shellfish were harvested. Almost half of the identified shellfish consisted of two species of whelk which appear to be locally extinct today. Bird bones are abundant. Analysis of the 1974 collections by David Yesner (1977) indicates a remarkable match with contemporary Kachemak Bay spring bird frequencies. Only a few autumn fledgling remains have been found. Many of the mammals taken were immature. Preliminary studies of growth rings in the shellfish $(\mathrm{N}=38)$ indicate that 80 percent were taken in the spring with the remaining 20 percent taken in fall. Several lines of evidence thus converge to suggest that the site was utilized mainly in the spring and early summer over a span of perhaps 800 years in middle to late Kachemak tradition times.

\section{Cottonwood Creek}

In 1974 we excavated at Cottonwood Creek (Fig. 1), the only substantial site on the bleak north shore of Kachemak Bay (W. Workman, 1977b). De Laguna had excavated here in 1930 and 1931 and ethnographic rumor had it that it was here that the first Tanaina Athapaskans came to Kachemak Bay, some generations before the coming of the Russians (de Laguna, 1934). Predictably, we did not find their footprints and our experience with this deep but fairly impoverished shell midden was much the same as de Laguna's had been. We invested about one man year of effort and were rewarded with fewer than 500 artifacts, exclusive of bone beads.

A level camping place, fresh water, and possibly favorable exposure to the winter sun appear to be the only advantages of this location at the mouth of the steep-sided Cottonwood Creek canyon. Fish do not run in the creek and the extensive mud flats appear to contain far fewer shellfish than were available at the time the site was occupied. Two components, clearly separated by 10 to 30 $\mathrm{cm}$ of sterile silt incorporating a thin volcanic ash, are present. Here our attention will focus on the lower or main component. Cultural deposits reached a depth of three meters in places and, compared to Chugachik, the matrix was very shelly. A special feature is the presence of huge bright orange beds of burned shell and lignite ash (de Laguna, 1934). These were artifactual deserts.

De Laguna recovered about 500 artifacts and placed the site in the latter part of Kachemak III (de Laguna, 1934), a judgment with which we fully concur. Notched stones were tiny and ulus were rare. In contrast with the Chugachik collection, stone flaking was almost nonexistent, with only seven chunks and chips recovered. Adzes, bone wedges, and other woodworking tools were also rare, but large sandstone grinding slabs of uncertain function were fairly common. Delicate barbed points, presumably arrowheads, and compound fishhook barbs were present but harpoon and barbed dart heads for the procurement of sea mammals were absent, although there were socket pieces for harpoons. In both sparsity and typology the 1974 collections replicate de Laguna's earlier 


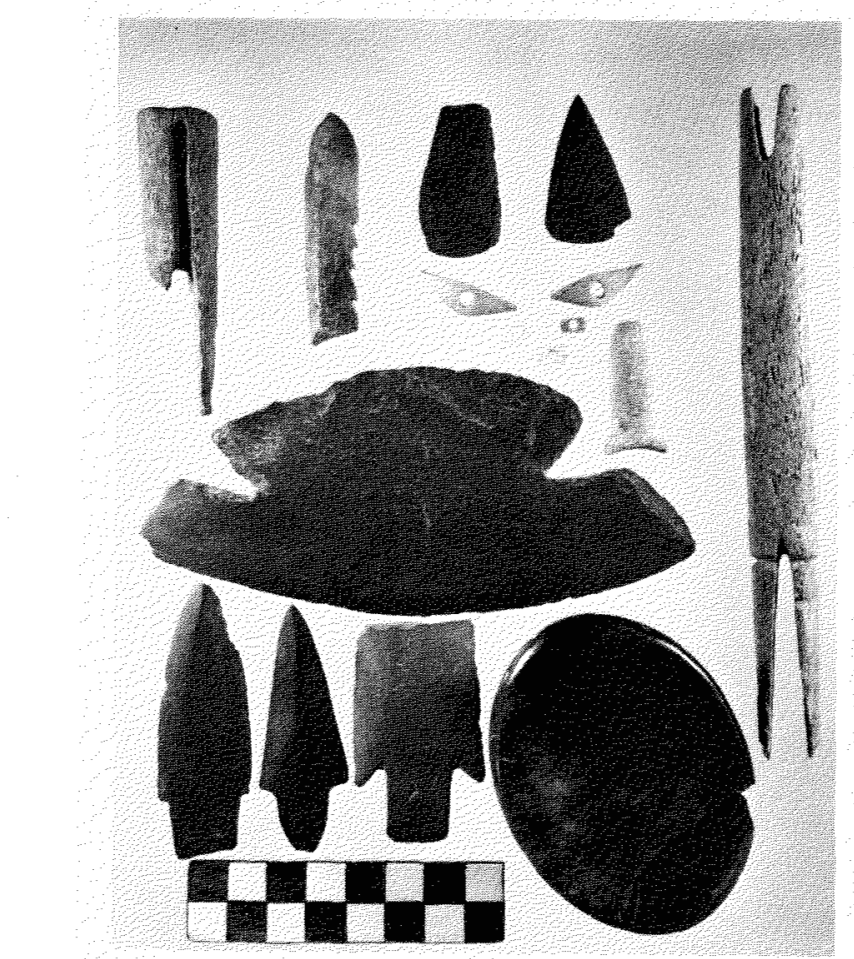

FIG. 3. Artifacts from the Cottonwood Creek Site (SEL 030).

Top Row (Upper Component): bone handle (?), broken bone point, two triangular slate endblades

Row Two (Main Component): Two artificial eyes and bone and shell beads associated with burials

Row Three: Notched ulu, small marble labret, large bone foreshaft

Bottom Row: Three barbed slate points, large circular labret from burial

finds to a remarkable degree, but we did recover abundant additional data on human remains and burial ceremonialism.

Eight burials yielded 13 individuals and at least eight more humans were represented by isolated bones (Lobdell, 1978). No deep grave pits were evident and corpses apparently were barely covered over with shells. The most common type of burial, found in five of eight cases, was simple interment in the flexed position without grave goods. A bone knife and a knife handle were associated with the burial of a child. Two very large labrets (Fig. 3), presumably for a mask, were found on the sternum of the fully articulated remains of a woman of late middle age. About 3300 bone and shell beads of the type illustrated in Fig. 3 were found about her neck, shoulders, arms, and upper chest. Presumably these were ornamentation on a parka, dance cape, or veil (de Laguna, 1975). Great wealth is represented in this grave lot, suggesting that some women achieved high status in late Kachemak tradition society. The other six burials were disarticulated, and absence of smaller elements such as phalanges suggests that some were secondary interments. One individual was compressed into a $30 \times 30 \times 30 \mathrm{~cm}$ 
space with the skull resting atop the pedestal formed by the innominate bones. Similar treatment, without the compression, was afforded to the male and female occupants of a multiple burial, and this was also the main form of burial encountered by de Laguna in her earlier work at the site (1934).

The most interesting burial came from the base of the site where the disarticulated remains of a middle-aged female, a young male and an infant were found. The teeth of both adults had been extracted and discarded elsewhere, a practice which de Laguna noted but failed to emphasize in her previous work (de Laguna, 1975). The iliac blades of the innominates of the adults had been perforated. Stylized artificial eyes (Fig. 3) had been placed in the orbits of the female and her face had been smeared with clay. A bone knife, presumably used in the burial festivities, had been tossed in with the bones, possibly after being intentionally broken. The female was in the advanced stages of a severe bone disease, probably a rare form of bone cancer known as malignant hemangioendothelioma (Lobdell, 1977; 1978). Given the evidence of several pathologic limb fractures and probable extreme pain, she must have been supported as a nonproductive member of society for some time before her death.

All of these burial practices have been previously reported from late Kachemak tradition contexts in Kachemak Bay and Kodiak Island (de Laguna, 1934; D. Clark, 1970), but the Cottonwood material provides new material with which to work. The complex ceremonial practices hinted at here cannot be decoded in detail because they did not endure into historic times. The Ipiutak people at Point Hope, far to the north, also buried their dead in shallow graves, sometimes accompanied by masks and artificial eyes, and possibly dismembered the corpses (Larsen and Rainey, 1948). Although Norton culture burial practices are poorly known, it can be predicted that when Norton cemeteries are discovered they will include some of the more esoteric practices shared by lpiutak and the late Kachemak tradition.

Our faunal data from Cottonwood Creek support de Laguna's conclusion that this was a late winter-early spring starvation settlement (1934). Sea mammal bones are rare, as are caribou, moose, bear and rabbit. Bird bones indicate winter or spring procurement. Fish remains again include bottomfish but no salmonids. The midden contains abundant clams unavailable in the impoverished local mudflat community today; their absence suggests significant sedimentation of the mudflats of the north shore of the bay since the main occupation, which we now know terminated some 1500 years ago (de Laguna, 1934). This sedimentation of the shellfish beds may have led to site abandonment since molluscs seems to have been one of the primary assets here.

The three acceptable radiocarbon dates for the site are presented in Table 1. The two oldest come from two semisubterranean houses dug into subsite deposits. The maximum 500-year span suggested for the accumulation of three meters of deposit does not seem altogether reasonable. Typology suggests a late Kachemak tradition placement, and the dates suggest partial contemporaneity with the uppermost portions of the Chugachik Island site deposits discussed earlier. This apparent temporal overlap is difficult to correlate with the artifactual evidence such as the profusion of flaked stone at Chugachik and its virtual 
absence at Cottonwood. Seasonal and activity differences between the two sites may provide a partial, but not a conclusive explanation.

\section{Later Prehistory}

Elsewhere around the Gulf of Alaska, sites of the last 1000 years tend to be more conspicuous than earlier ones. This is not the case in Kachemak Bay, where sites of later prehistoric times are poorly represented and most of the known sites are of Kachemak tradition affinity.

At the time of the coming of the Russians in the 18th century much of Kachemak Bay was in Tanaina Athapaskan hands (de Laguna, 1934; Osgood, 1966). These Indians had an Eskimoid material culture, using skin boats and harpoons to hunt sea mammals, wearing gut parkas, etc. (Osgood, 1966). The time and circumstances of the penetration of the Tanaina to salt water and the mechanisms that allowed them to supplant a stable and successful Eskimo adaptation badly require explanation. We cannot promise that, but we can examine the evidence for post-Kachemak tradition occupation of the bay.

On the basis of scant material from the uppermost levels at the Great Midden site on Yukon Island and elsewhere, de Laguna (1934) defined a Kachemak IV period of culture. Prominent features of the small assemblage are two tiny scraps of pottery and several native copper artifacts from the Great Midden, and a triangular butt-faceted ground slate end blade of Second Millennium A.D. aspect from Passage Island.

We encountered a small but distinctive upper component in our work at Cottonwood Creek (Fig. 3, top). This material was clearly separated from the main occupation by $10-30 \mathrm{~cm}$ of sterile silt which incorporates a volcanic ash. The 17 artifacts include a greenstone grooved (splitting) adze and two triangular stemless slate end blades not documented for the Kachemak tradition. Also found was an intricately carved bone handle (possibly for a knife), a bilaterally barbed bone point fragment, a beaver tooth, several large grinding slabs, and two flaked stone chunks. The skull of a small, short-faced dog with canines intentionally broken out was found in the midden debris. A large radiocarbon sample yielded a date compatible with the main occupation beneath and is unacceptable on stratigraphic and typological grounds (W. Workman, 1977a). While it might be presumptuous to raise questions of ethnic identity with such a small sample, the material is clearly outside the Kachemak tradition and should date to the Second Millennium A.D. on the basis of diagnostic artifacts such as the grooved adze and triangular slate points. It appears more likely to be of Eskimo than of Indian manufacture.

In the summer of 1978 we excavated an important late First Millennium A.D. site perched atop a forty-foot bluff behind the previously known Yukon Island Fox Farm site (Workman and Lobdell, 1979). Although the site had a fairly complex history, the bulk of the material is associated with a dark soil that appears to date from the latter half of the First Millennium A.D. (Table 1). We provisionally interpret this material as an assemblage reflecting seasonal and sporadic use of this site over at least several centuries. 


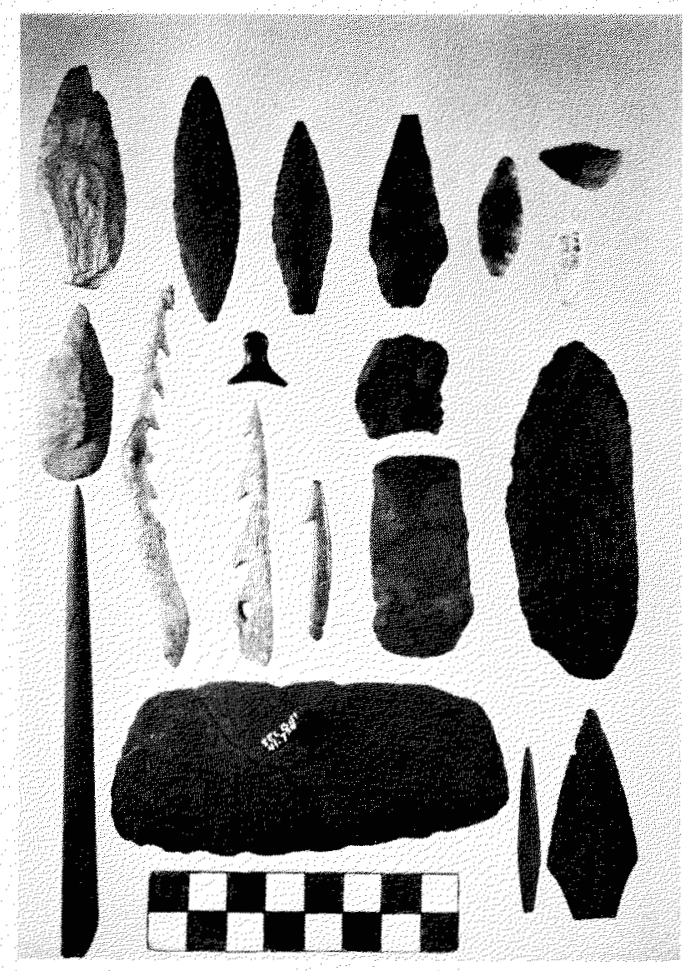

FIG. 4. Artifacts from the Yukon Island Bluff Site (SEL 041 Bluff).

Top row: Flaked and ground burin, five bifaces, sideblade

Row Two: Flaked stone drill, small jet labret, chert wedge

Row Three: Bone leister side prong, barbed dart, compound fishhook barb, greenstone adze, basalt biface

Bottom Row: Ground slate rod, slate ulu, two ground slate points

Organic artifacts, preserved only in discrete pockets of shell midden, compare with North Pacific forms predating 1000 A.D. (Fig. 4). There is a surprising dependence on flaked stone in the assemblage, reversing a Kachemak tradition trend towards increasing dependence on artifacts of ground slate. Small bipoints, a probable side blade, a drill, and a ground stone burin-like tool are similar to Norton-related forms to the north. Stone wedges are abundant. Many of the finished flaked artifacts are of exotic stone such as basalts, high quality chert, chalcedony, and even obsidian, rather than the locally available low-grade red or green cherts. Ground slate rods are a Kachemak tradition form, but typical Bluff site ulus lack the hafting notches typical of that tradition (de Laguna, 1934). Planing adzes have the symmetry and finish typical of the late Kachemak tradition.

We recovered the first significant collection of pottery from Kachemak Bay, with substantial portions of three vessels represented. The pots are moderately thick, primarily gravel-tempered, and usually globular in form. Curvilinear surface impressions are present and the rims are simple. Preliminary analysis suggests that pottery was introduced after the initial occupation of the site. 
Three radiocarbon dates suggest a late First Millennium A.D. placement for the bulk of the collection (Table 1). While some continuity with the Kachemak tradition is seen, certain of the flaked stone artifacts and the ceramics are clearly related to late First and early Second Millennium A.D. assemblages on the Alaska Peninsula (G. Clark, 1977). Although the Kachemak tradition persisted until c. 1100 A.D. on Kodiak Island (D. Clark, 1970), we now have reason to think that its grip on Kachemak Bay had loosened by or shortly after 500 A.D. This is based on our inability to get later radiocarbon dates on late Kachemak tradition material in Kachemak Bay, and the data from the Yukon Island Bluff site which clearly indicate a strong incursion of northern ideas into the virtual capital of the tradition shortly after 500 A.D. Between 1000 B.C. and 500 A.D. Kachemak Bay prehistory was closely related to the prehistory of Kodiak Island, but shortly after 500 A.D. it became aligned with Alaska Peninsula cultures, which were in turn under strong and increasing influence from the Bering Sea Norton culture (G. Clark, 1977). The distribution and fate of this peninsular-influenced culture in Kachemak Bay is unknown, and the dynamics of the Kachemak tradition abandonment of its ancient homeland are not understood. It appears that the Kachemak Bay vacuum into which the Tanaina Athapaskans eventually expanded came into existence over 1000 years before the Russians arrived.

Change on this scale should have discernible causes, but the faunal data from the Bluff site are not illuminating on this score. The Bluff site people depended on seals and porpoises in about the same proportions as their Kachemak tradition predecessors had. High frequencies of immature individuals suggest both selective hunting strategies and warm season occupations of the site. Growth line studies of a small sample $(\mathrm{N}=16)$ of shells from the Bluff site indicate harvesting evenly divided between spring and fall with no summer or winter shells.

Despite quantitative analysis of a mass of faunal data, the only significant faunal changes we have detected in Kachemak Bay prehistory are the disappearance of whelks at Chugachik Island and the disappearance of certain other types of shellfish at Cottonwood Creek after the sites were abandoned. A more refined Kachemak tradition subsistence model which embraces areas outside Kachemak Bay proper is clearly needed. Frequency data reveal only what animals were procured, not how easy they were to procure or how abundant the resource was. Refined analytical techniques are needed to attack this problem.

\section{STUDIES IN HUMAN BIOLOGY}

An expanded Kachemak tradition skeletal series (Lobdell, 1978) has allowed us to reopen the question of who these people were in biological terms and has shed some new light on life and death in late Kachemak tradition times. A minimum of 34 individuals are present in the series, many represented only by fragments. Twenty-one can be assigned to general age categories. Infant and child mortality was high: $12 \%$ of the sample consisted of infants and $30 \%$ of individuals who did not survive beyond 10 years. A profound, and probably spurious, differential mortality pertains for men and women. Mean age at death 
for four females was about 50 years and mean age at death for six males was 22 years. An adjusted mean age at death for the 21 individuals for whom fairly precise determination was possible is about 25 years. Clearly it was possible to live to an advanced age in Kachemak tradition society if one survived the rigors of childhood, expecially if one were female.

Cottonwood Creek is interpreted as a cold season starvation village and we doubt that it is chance alone that we acquired our best skeletal sample there. Shallow burials and dismembered human remains might well represent accommodations to deaths in a cold season.

Pathologies are present in six of the 13 burials from Cottonwood Creek, with degenerative joint diseases in middle-aged women being the most common. Bone cancer in one female has been mentioned. Surprisingly few fractures, healed or otherwise, were noted. Periods of malnutrition are indicated by enamel hypoplasia in the teeth of four individuals and a high incidence of growth arrest lines in long bones. One adolescent male had nearly as many growth arrest lines as he had years of life. These data indicate that adequate nutrition was interrupted by recurring lean times, almost certainly in the late winter and early spring. These somber facts of life must be taken into account when we evaluate the abundant evidence for cultural well-being and vitality among these people.

Biological distances were calculated between a very modest series of six late Kachemak tradition adult male skulls and other Alaskan coastal populations for whom comparable data were available. Cranial and facial measurements were utilized to calculate Penrose's shape distances. As anticipated, the Kachemak tradition series clusters quite closely with the Prince William Sound series and fairly closely with the Pre-Koniag (presumably Kachemak tradition) series from Kodiak. Surprisingly, the Ipiutak people from Point Hope are almost as close to the Kachemak tradition series as the Prince William Sound people are, and the Koniag of Kodiak Island are least similar of all populations compared, despite convincing evidence that the Kachemak tradition on Kodiak Island contributed significantly to the genesis of the late prehistoric Koniag phase (D. Clark, 1974). Serious problems exist with the Kodiak data, however, attributable mainly to the inadequate field techniques and data recording of Aleš Hrdlička (D. Clark, $1974 ; 1975)$. It is now possible to assert on morphological evidence what we have suspected all along on cultural grounds, that the Kachemak tradition people were Pacific Eskimos.

\section{SUMMARY}

Our work in Kachemak Bay has advanced our understanding of this area to a modest extent. The artifact sample for late Kachemak II and Kachemak Sub-III has been significantly expanded, and additional data have been compiled on burial ceremonialism. Studies of human biology have provided more information about life and death in late Kachemak tradition times and tentative statements about population relationships, including the firm identification of these people as Pacific Eskimos, can now be put forth. Quantified faunal data covering a span of 1500 years indicate a relatively stable predation on harbour seals and porpoises regardless of variables such as upbay or outbay site location, chronol- 
ogy, site seasonality, and even cultural affiliation. The questions associated with the coming of the Tanaina Athapaskans to Kachemak Bay have yet to be answered; however, our information from the Yukon Island Bluff site suggests that there was a hitherto undetected influx of northern ideas late in the First Millennium A.D. and that Kachemak tradition peoples had probably withdrawn from much of the bay by that time. It now seems clear that other non-Kachemak tradition peoples preceded the Tanaina in utilizing the bay, and that no direct Kachemak tradition - ancestral Tanaina transition is to be expected. Attempts to explain this situation in social terms and to understand the mechanisms involved provide topics for continuing research.

\section{ACKNOWLEDGEMENTS}

This work was made possible by the support of the University of Alaska, Anchorage and Anchorage Community College, by grants from the Otto William Geist Fund in 1974 and the National Endowment for the Humanities in 1977, and by the interest of students and local residents. We publicly acknowledge our debt to Professor Frederica de Laguna upon whose solid foundation we have attempted to build and who worked with us in the summer of 1978, returning to Yukon Island where she had last worked 46 years earlier.

\section{REFERENCES}

STATE OF ALASKA DEPARTMENT OF FISH AND GAME. 1978. Alaska's Fisheries Atlas. Volume 1. Tacoma: Print Northwest.

BANDI, HANS-GEORG. 1969. Eskimo Prehistory. College, Alaska: University of Alaska Press.

CLARK, DONALD W. 1966. Perspectives in the prehistory of Kodiak Island, Alaska. American Antiquity 31(3): 358-371.

1970. The late Kachemak tradition at Three Saints Bay and Crag Point, Kodiak Island, Alaska. Arctic Anthropology 6(2): 73-111.

1974. Koniag Prehistory. Tübinger Monographien zur Urgeschichte Band 1. Stuttgart: Verlag

W. Kohlhammer.

1975. Technological continuity and change within a persistent maritime adaptation: Kodiak

Island, Alaska. In: Fitzhugh, William (ed.). Prehistoric Maritime Adaptations of the Circumpolar

Zone. The Hague: Mouton. pp. 203-227.

1979. Ocean Bay: An early North Pacific maritime culture. National Museum of Man Mercury Series, Archaeological Survey of Canada Paper No. 86. Ottawa.

CLARK, GERALD H. 1977. Archaeology on the Alaska Peninsula: The coast of Shelikof Strait 1963-65. University of Oregon Anthropological Papers No. 13. Eugene, Oregon.

DE LAGUNA, FREDERICA. 1934. The Archaeology of Cook Inlet, Alaska. Philadelphia: University Museum. Reprinted with a new preface in 1975 by the Alaska Historical Society, Anchorage.

1975. Preface. In: The Archaeology of Cook Inlet, Alaska. Alaska Historical Society, Anchorage. iii-xi.

. and WORKMAN, KAREN WOOD. 1979. Further testing at the Fox Farm site (SEL 041).

Paper presented at the Sixth Annual Meeting of the Alaska Anthropological Association, Fairbanks. Ten page manuscript in the files of the authors and at the Arctic Institute of North America, Calgary, Alberta, T2N $1 \mathrm{~N} 4$.

DUMOND, DON E. and MACE, ROBERT L. 1968. An archaeological survey along Knik Arm. Anthropological Papers of the University of Alaska 14(1): 1-22.

GIDDINGS, J.L. 1964. The Archeology of Cape Denbigh. Providence: Brown University Press.

JACOBSEN, JOHAN ADRIAN. 1977. Alaskan Voyage 1881-1883: An Expedition to the Northwest Coast of North America. Translated by Erna Gunther from the German text of Adrian Woldt. Chicago: University of Chicago Press.

KARLSTROM, THOR N.W. 1964. Quarternary geology of the Kenai Lowlands and glacial history of the Cook Inlet Region, Alaska. Geological Survey Professional Paper No. 443. Washington: Government Printing Office. 
LARSEN, HELGE and RAINEY, FROELICH. 1948. Ipiutak and the arctic whale hunting culture. Anthropological Papers of the American Museum of Natural History No. 42. New York.

LOBDELL, JOHN E. 1977. The occurrence of a rare cancer in a prehistoric skeleton from Kachemak Bay, Cook Inlet, Alaska. Paper presented at the 30th Northwest Anthropological Conference, Victoria. Ten page manuscript in the files of the authors. Revised version accepted for publication in National Museum of Man Mercury Series, Jerome Cybulski (ed.).

1978. The osteology of the Kachemak Eskimo. Fifty page manuscript in the files of the authors and at the Arctic Institute of North America, Calgary, Alberta T2N 1 N4.

LUTZ, H.J. 1974. An ecological mystery. In: Sherwood, Morgan (ed.). The Cook Inlet Collection. Anchorage: Alaska Northwest Publishing Company. pp. 27-30.

NOWAK, MICHAEL. 1974. Final report to the National Science Foundation: The archeology of Nunivak Island, Alaska (Grant GS-3023). Thirty-six page manuscript in the files of the authors.

OSGOOD, CORNELIUS. 1966. The ethnography of the Tanaina. Yale University Publications in Anthropology No. 16. Human Relations Area Files Press. Reprint of the original 1937 edition. New Haven: Yale University Press.

U.S. DEPARTMENT OF COMMERCE. 1977. Environmental Assessment of the Alaskan Continental Shelf. Interim Lower Cook Inlet Synthesis Report. U.S. Department of Commerce, National Oceanic and Atmospheric Administration, Environmental Research Laboratories.

WORKMAN, KAREN WOOD. 1977. Chugachik Island: A Kachemak tradition site in upper Kachemak Bay, Alaska. Anthropological Papers of the University of Alaska 18(2): 1-22.

1978. The second season at Chugachik Island (SEL 033), Kachemak Bay, Alaska. Paper presented at the Fifth Annual Meeting of the Alaska Anthropological Association, Anchorage. Nine page manuscript in the files of the authors and at the Arctic Institute of North America, Calgary, Alberta T2N $1 \mathrm{~N} 4$.

and WORKMAN, WILLIAM B. 1975. The archeology of Cook Inlet after 45 years: an appreciation. In: de Laguna, Frederica. The Archaeology of Cook Inlet. Alaska. Second edition. Anchorage: The Alaska Historical Society. i, ii.

WORKMAN, WILLIAM B. 1977a. New data on the radiocarbon chronology of the Kachemak Bay sequence. Anthropological Papers of the University of Alaska 18(2): 31-36.

1977b. 1974 excavations at Cottonwood Creek (SEL 030): Report on work in Kachemak Bay under State of Alaska permit 1974-9. Nineteen page manuscript in the files of the authors.

1980. Continuity and change in the prehistoric record from southern Alaska. Senri Ethnological Studies No. 4: 49-101. National Museum of Ethnology, Osaka, Japan.

. and LOBDELL, JOHN E. 1979. The Yukon Island Bluff site (SEL 041): A new manifestation of late Kachemak Bay prehistory. Paper presented at the Sixth Annual Meeting of the Alaska Anthropological Association, Fairbanks. Twelve and ten page manuscripts in the files of the authors and at the Arctic Institute of North America, Calgary, Alberta T2N 1N4.

YESNER, DAVID R. 1977. Avian exploitation, occupational seasonality, and paleoecology of the Chugachik Island site. Anthropological Papers of the University of Alaska 18(2): 23-30. 